\title{
The Covid-19 Impact on the Tourism Industry: Short Holidays within National Borders*
}

\author{
Antonella Reitano ${ }^{* *}$, Marco Fazio ***, \\ Francesco Schirripa Spagnolo $^{* * * *}$, Nikolaos Karanasios ${ }^{* * * * *}$
}

\begin{abstract}
The COVID-19 pandemic has heavily hit international economy giving a particular setback to the tourism sector. Between March and May 2020, during the first lockdown, and between October and December of the same year, during the second lockdown, a questionnaire was administrated in Italy, Greece and Great Britain. Through the questionnaire, people's feelings and expectations of their desire to take a vacation were collected regarding the period of constraint due to the new coronavirus and the possible end of the pandemic, or the first government approved travel openings. In particular, the question of how long it would take to decide on a holiday, the type and duration, after the period of constriction due to the coronavirus was over, was asked. Both surveys, in the two different lockdown periods, showed the potential desire of tourists to leave relatively quickly, and to take forms of domestic tourism, characterized by small and short-lived trips. The favorite destination being the seaside.
\end{abstract}

Keywords: Covid-19; Coronavirus; Global Tourism; Domestic Tourism; Holidaymakers' Expectations; Sustainable Tourism; Global Markets

\section{Tourism Industry in Times of Crisis}

The tourism sector is an economic sector of primary importance for many countries, to the point that any drop is a cause of concern for governments due to the repercussions on the other production sectors and the related service industry: airlines, hotels, restaurants and enogastronomy (Reitano et al., 2016), and shops. Tourism is currently a global and highly competitive industry and, for these reasons, very sensitive to the perception of danger and the lack of security (Brondoni, 2016). Very often it is described as a fragile sector for travel demand is highly susceptible to numerous "shock events", such as wars, epidemics of contagious and fatal

\footnotetext{
* The Authors: Reitano, A. §§ 2; Fazio, M. §§ 1, 3, 4, 4.1, 4.2; Schirripa Spagnolo, F. § 4.3; Karanasios, N. § 5.

** Associate Professor of Marketing and Management of Tourism Businesses, University of Calabria (antonella.reitano@unical.it)

*** Adjunct Professor of Neuromarketing Techniques, University of Calabria (marco.fazio@unical.it)

***** Lecturer on Statistics, University of Pisa (francesco.schirripa@ec.unipi.it)

****** Assistant Professor of Business Administration, International Hellenic University (bicofserres@ gmail.com)

Edited by: Niccolò Cusano University

ISSN: $1593-0319$

Reitano, A., Fazio, M., Schirripa Spagnolo, F., \& Karanasios, N. (2021). Covid-19 Impact on the Tourism Industry: Short Holidays within National Borders. Symphonya Emerging Issues in Management (symphonya.unicusano.it), (2), 85-98.
}

https://dx.doi.org/10.4468/2021.2.08reitano.fazio.schirripa.karanasios 
diseases, terrorist attacks, economic fluctuations, monetary instability, and energy crises (Bonham et al., 2006). Safety and protection have always been critical conditions for tourists and travelers (Brondoni, 2016) who, during their travels, certainly do not like to be exposed to personal risks and dangers of any kind. It is therefore not surprising that wars, pandemics, terrorist attacks or other threats affect the propensity to travel. Some types of events allow changes of course, to destinations without risk, others do not, such as the pandemic from Covid-19.

Numerous breakdown events, of different nature in the last twenty years, have exposed global tourism to different periods of crisis. These have included the terrorist attacks of September $11^{\text {th }}$ and the invasion of Afghanistan in 2001, the bombings of Bali in October 2002, the epidemic of severe acute respiratory syndrome (SARS) and the war in Iraq in 2003, the Madrid train bombings (March 2004), the destructive tsunami in the Indian Ocean (December 2004) the London bombings (July 2005), the global economic crisis taking place in 2008/09, the Middle East respiratory syndrome (MERS) in 2015. All of them have had an impact on the tourism economy of the directly affected countries and neighboring areas, none of which, however, has led to a long-term decline in global tourism development (Gossling et al., 2020). For example, the events of September $11^{\text {th }}$ had a strong impact on America's tourism economy, in particular on the air transport industry (Ready \& Dobie 2003; Lambin, 2002), highlighting the negative effects of terrorism and anti-terrorism measures on the performance of the entire sector. The sector's vulnerability to negative external events, such as terrorism, has defined the growing importance of managing tourism security in a global approach as an integral part of the entire sector (Brondoni, 2016). According to a report from the World Travel and Tourism Council, tourism takes about 13 months to recover from a terrorist attack. The study also found that, by comparison, tourism takes longer to recover from disease (21 months), an environmental disaster (24 months) and political unrest (27 months) (Zillman, 2015).

On December $31^{\text {st }}, 2019$, the World Health Organization (WHO) warned everyone about the occurrence of particular pneumonia cases found in the city of Wuhan, China (Lee, 2020). A new coronavirus (Covid-19) was starting to spread very quickly, so much so that by the end of January 2020, the cases found in China were almost 10,000 with another 15,238 su spected cases ${ }^{1}$. By mid-March, the diffusion of the new acute respiratory syndrome, had already spread to 146 countries (Gossling et al., 2020). In less than six months, Covid-19 proved to be a bigger pandemic than any other in recent history (Dong et al., 2020). Since, as already mentioned, there is a strong link between tourism and the risk of catastrophes for health, governments have been forced to impose travel bans in order to contain the risks of transmission of the virus (Gossling et al., 2020; Yang et al., 2020). From the moment we started talking about coronavirus, the scenery has changed every day. At first the most common sentiment was disbelief. In Europe, the news that came, however disturbing, concerned a distant country, China. In a few weeks, however, the virus from China arrived in Italy and, within a short period of time, it spread over Europe, transforming disbelief into anxiety and fear. Governments had to take drastic measures to contain the virus: isolation and quarantine first, social distancing then followed. During the period of constraint, of isolation, the common questions were: will it be possible to resume a normal life? Will we be able to hug each other? What will be the level of the economic crisis? How long will we be forced to avoid relationships, socialization, and travel? 
In this context of crisis and economic and social uncertainty, the present research aims to investigate the status and expectations of people in relation to travel and tourism. For this purpose, a questionnaire was administered both during the first lockdown period (March-May 2020) and during the second (October-December 2020) to a heterogeneous sample of people living in Italy, Greece and the United Kingdom. The aim was to investigate the attitude of the people towards tourism and travel during the pandemic, in particular, how long after the end of the coronavirus restrictions, people would feel safe in taking a pleasure trip. Moreover, the survey allowed the acquisition of information regarding the preferences of consumertourists for their first pleasure trip after the restrictions: type, destination and duration. The repetition of the questionnaire allowed the comparison of the two different periods of restriction, undoubtedly characterized by different feelings.

\section{Tourism Flows and Disruptive Events}

An event that suddenly turns into an unfavourable situation is commonly referred to as a "crisis" (Laws \& Prideaux, 2005). The safety of travelers is a factor of primary importance in the tourism sector, therefore investments in the sector must always be oriented towards the ability to offer safe destinations (Brondoni, 2016). After the September $11^{\text {th }}$ attacks in New York and Washington, passengers massively abandoned the airports; the effects of these attacks have also extended beyond the United States with serious consequences for the airlines (Brondoni, 2016).

Severe acute respiratory syndrome (SARS) was the first pandemic of the $21 \mathrm{st}$ century (Peiris et al., 2003); its first outbreak was in mainland China in November 2002 (Zhong et al., 2003). The SARS epidemic created much anxiety at an international level due to the lack of knowledge of the virus, the ease of transmission and the speed of diffusion, especially through travel (Wilder-Smith, 2006). At that time, the psychological impact of SARS, combined with travel restrictions imposed by various national and international authorities, significantly reduced travel. Governments and the press, especially in the affected areas, were slow to find the right balance between timely communication and risk contextualization. On July $5^{\text {th }}$ 2003, WHO declared the end date of the SARS epidemic. During the SARS epidemic period, according to data from the World Tourism Organization (WTO), the arrivals of international tourism recorded a drop of $1.2 \%$, for a value of 694 million euros in the year 2003. In East Asia alone, the drop in arrivals in the first days of April 2003 was down $41 \%$ on the same period of the previous year. The destinations that suffered most were China, Hong Kong, Vietnam and Singapore. In the months of the outbreak, an estimated 12 million arrivals to Asia and the Pacific dropped. According to the then Vice President of Research and Economics at the World Travel and Tourism Council (WTTC), Rick Miller, the impact of SARS on these countries had been four or five times the impact of September $11^{\text {th }}$ in the States. In the first five months of 2003, arrivals of foreign and domestic tourists to Beijing decreased by 480,000 and 8.7 million, respectively, generating losses of US $\$ 1.3$ billion. Many major scheduled events were cancelled in the areas involved. Some airlines, due to declines in travelers, were forced to lay off workers to bear the costs of the crisis. A sharp drop in customers also occurred in Chinese cuisine restaurants in Guangdong, Hong Kong and Chinatown in North America. On December $31^{\text {st }} 2019$, the WHO National Office 
in China reported the presence of a new form of pneumonia of unknown cause (Gossling et al., 2020). At the beginning of January 2020, 41 patients with infections confirmed by the new coronavirus (COVID-19) were sent to hospital in China. This was the beginning of a new pandemic on a global scale and a lockdown period characterized by quarantine, social distancing and restriction for all, such as the closure of schools, universities, companies, non-essential workplaces, non-essential commercial activities, and the cancellation of events. By mid-March, the propagation of the new severe acute respiratory syndrome coronavirus 2 (SARS-CoV-2) from China had reached 146 countries (Gossling et al., 2020). The restriction on international, regional and local travel immediately hit national economies, including the global tourism chain. With the slowdown of domestic and international flights due to restrictions imposed by many countries, international tourism plummeted in the course of a few weeks. Those who were outside had to hurry back home; cruise ships became the worst scenery for anyone travelling during the period of the first closure. Between February and March 2020, numerous ships recorded cases of COVID-19 infection on board (Mallapaty, 2020) and, at the end of March, a dozen remained at sea unable to find a port that would welcome them to dock. The idealized safe environments (Cordesmeyer \& Papathanassis, 2011) at sea turned into traps, with thousands of passengers being kept in quarantine in their cabins in order to face the challenge of returning home. In China, home of the first Covid-19 outbreaks, the spread of the virus immediately generated a strong setback to tourism. The tourists present at the time of the first closures were brought back, accesses were increasingly limited, many national and international flights were cancelled. Many cruise lines, such as the Norwegian Cruise Line and Royal Caribbean, also immediately stopped sailing to and from China (Hoque et al., 2020). Outgoing tourism also remained involved: over $10 \%$ of the world's tourists are Chinese. Already in the early months of 2020, several nations such as Great Britain and the United States had suspended their trade and travel relationships with China because of the virus (Hoque et al., 2020). During the same period, many travelers cancelled holidays and vacations targeting the regions of Southeast Asia, such as Beijing, Shanghai, Xi'an, Chengdu, China, or Malaysia and Singapore, diverting to other destinations such as Southern Africa, the Maldives and Australia. In conclusion, the travel and tourism system can be considered a complex adaptive system characterized by unpredictable behaviors. Strategic forecasting and scenario planning represent a methodology to monitor and understand the travel and tourism system. At the same time, they permit the anticipation of future system developments, to identify strategic courses of action, to contribute to the resilience and sustainability of the travels and tourism sector and maintain it productive for a long time (Postman \& Yeoman, 2021). This tool can be used to develop adaptive skills; to help a destination, organization or company to adapt and harness natural resilience abilities, rather than trying to control it and prevent changes from occurring (Miller \& Twining-Ward, 2005).

\section{Pandemics and Travel}

Relationships between pandemics and travel are fundamental in order to understand health security and global change (Burkle, 2006). 
Before the pandemic, destinations such as Venice, in Italy, or Barcelona, in Spain, were characterized by the phenomena of over-tourism. It led to search for solutions to handle this situation, in particular for the wellbeing of local inhabitants and tourists, as well as the protection of the environment and the territory. The pandemic, the anxieties and fears of citizens as well as the relative restrictions imposed by governments on travel and transportation, eliminated tourists in all destinations (Higgins-Desbiolles, 2020). The research to date has provided results regarding the effects of the pandemic on individual national systems but not on the entire world tourism system as a whole (Gossling et al., 2020). Several studies have highlighted the important role of air transport in accelerating and amplifying the spread of viruses (Brown et al., 2016). There have been several outbreaks in the past 40 years, but none have had implications on the global economy similar to those related to Covid-19 (Gossling et al., 2020). Among the major viral outbreaks of the past 40 years, with different levels of mortality, we can identify the following (Skare et al., 2020):

Table 1: Infections and Deaths from Viral Epidemics in Recent Years

\begin{tabular}{|l|c|c|}
\hline \multicolumn{1}{|c|}{ Outbreaks } & Infections & Deaths \\
\hline Ebola* (1976) & 33,577 & 13,562 \\
\hline Hendra (1994) & 7 & 4 \\
\hline H5N1 bird flu (1997) & 861 & 455 \\
\hline Nipah (1998) & 513 & 398 \\
\hline SARS (2002) & 8096 & 774 \\
\hline H1N1** (2009) & $762,630,000$ & 284,500 \\
\hline MERS*** (2012) & 2494 & 858 \\
\hline H7N9 bird flu (2013) & 1568 & 616 \\
\hline * as of January 31, 2020; ** between 2009 and 2010; *** as of November 2019. \\
\hline
\end{tabular}

Source: Science Alert, 2020

For the tourist sector, the impact of these epidemics on arrivals depends on the source and distance to the virus outbreak source (ground zero countries) (Skare et al., 2020). Viral epidemic diseases, such as SARS (2002) and H1N1 (2009), have a large and significant impact on global tourism trends and on economic opportunities. On the other hand, epidemics with lower infectious rates, have a lower impact on tourism trends and related economic losses. Epidemics and pandemics cause a decline in tourist flows. The United Nations World Tourism Organization (UNWTO) estimates that, during the epidemics in the period from 1980 to 2019, the total amount of tourist worldwide decreased by about 57 million. In America, the 2002 SARS epidemic and H1N1 (2009) caused a significant drop in tourist arrivals, 10 million; as well as in tourism spending, approximately US \$21 billion (Skare et al., 2020). In the Asian and Pacific regions, there was a significant decline in tourist arrivals during the avian flu epidemic (1997), SARS (2002) and H1N1 (2009). Lost arrivals during the avian flu crisis in that region were 1 million. During the SARS epidemic (2002), the drop in tourist arrivals to the region reached 12 million with a loss in revenue of US \$2 billion. During the H1N1 crisis (2009), the tourists entering the region decrease by 3 million with a US $\$ 6$ billion loss in tourism (Skare et al., 2020). Due to the distance from the region of origin of the virus, the EU was not seriously affected by the 
majority of epidemics from 1980 to 2019 (Skare et al., 2020). However, during the H1N1 epidemics (2009), there was a decline of 26 million tourist arrivals and a loss of total tourism spending of US \$61 billion (equal to 0.5\% of the EU GDP) (Skare et al., 2020). The H1N1 epidemic hit the EU with a high loss in tourist arrivals and the loss of expenditure exceeded the economic impact in all other world regions in the period 1980-2019.

The situation caused by the coronavirus pandemic in 2020 does not resemble any of the previous situations. It can be said that it is a global crisis, accompanied by a ban on travel in any form and for any purpose. The duration of the crisis was prolonged without being able to set a date for the end of the restrictions, moreover, a new wave of pandemic diseases was expected, which could reduce tourism again (Nepal, 2020).

As numerous cases of Covid-19 have occurred globally, travel restrictions have extended from the epicenter of the Whuan region (local block since January 23) to most countries as early as the end of March. During this period, over $90 \%$ of the world's population was in locations with some degree of movement restrictions, border closures and quarantines (Gossling et al., 2020).

\section{Research Design and Methods}

The data collection was carried out during the lockdown, between 4 April and 4 May, 2020. A snowball sampling technique was used in order to find participants for the study. Snowball sampling or chain-referral sampling is defined as a nonprobability sampling technique in which the samples have traits that are rare to find. This is a sampling technique, in which existing subjects provide referrals to recruit samples required for a research study (Goodman, 1961). The main aim of the study has been to investigate the propensity to travel for pleasure after the end of the pandemic or when the governments will allow it. For this aim, the questionnaire included questions related to the time span, after the period of COVID restrictions, in which people would decide to take a pleasure trip, as well as the type and the length of the first pleasure trip. The survey was replicated during the second lockdown, October-December 2020.

\subsection{The Study During the First Lockdown}

\section{Reference Sample}

A questionnaire was implemented in Italy, Greece and United Kingdom. A total of 1,346 questionnaires were collected with $59.76 \%$ of the respondents being female, the remaining percentage male; the average age of the sample was 41.05 (median 39.00 ), minimum age 18 and maximum 83 . Only $17.3 \%$ of the sample did not spend the lockdown period in the same place where they study/work or habitually live. While $53.3 \%$ experienced the lockdown in the central area, $34.22 \%$ were in the peripheral area, and the remaining $12.47 \%$ in the countryside or agricultural area. 


\section{Data Analysis}

$48.48 \%$ of the interviewees said that before the coronavirus lockdown period, they moved from their usual residence for leisure travel with a frequency of "1-2 times a year", 28.29\% "3-5 times a year", 18.34\% even "more than 5 times a year" and only $4.9 \%$ "never". A big portion of respondents, $57.02 \%$, said they had been forced to cancel a scheduled pleasure trip due to the time of compulsion for coronavirus. When asked "when, after the period of compulsion due to coronavirus, will you take a vacation?", $34.37 \%$ of respondents said "after 2-3 months", $22.79 \%$ replied "after 45 months" and $11.28 \%$ answered "during the first month". Among these, $21.46 \%$ said they were willing to leave for a holiday at least "after 1 year" from the reopening and the remaining $2.23 \%$ answered "never". The preferred destinations for the first trip were seaside destinations $(42.36 \%)$, followed by trips for visits to distant relatives/friends $(21.22 \%)$, cities of art $(10.34 \%)$ and capitals $(8.44 \%)$. After the closing period, no desire to move to less crowded places was recorded, these were closer to the concepts of social distancing, such as agritourism (1.29\%), villages $(2.36 \%)$ and mountain areas $(4.49 \%)$. As for the duration of the first post lockdown pleasure trip, the trend was for short periods; weekends $(41.76 \%)$ and one week holidays (36.86\%). Only 16.64\% imagined a vacation lasting between 7 and 15 days, $2.98 \%$ lasting one month, and $1.76 \%$ for more than a month. A touristic quality/ecolabel brand (such as blue or green flag certification) is not considered an important factor by respondents. Only $8.27 \%$ of respondents consider the tourist quality/eco-label very important (on a Likert scale from $1=$ not at all, to $5=$ a lot). For $34.52 \%$ this was moderately important and $38 \%$ gave a score between 1 (not at all) and 2 (a few). A high $81.3 \%$ of Italians said they prefer their country as the destination for the first post lockdown trip; the same trend was also found for Greek citizens as $84.5 \%$ preferred their domestic nation of residence. The same did not happen in Great Britain, where for $47.5 \%$ of respondents, Europe is the preferred destination for the first trip after the reopening.

Table 2: Contingency Table: "Country of Residence" - "Preferred Destination for the First Trip"

\begin{tabular}{|c|c|c|c|c|c|c|c|c|}
\hline & \multicolumn{8}{|c|}{$\begin{array}{l}\text { Which destination will you choose for your first trip when the time of confinement } \\
\text { at home due to the coronavirus is over? }\end{array}$} \\
\hline $\begin{array}{l}\text { Country of } \\
\text { residence }\end{array}$ & & & Other & Europe & Greece & Italy & UK & Total \\
\hline & Greece & 2 & 2 & 11 & 93 & 2 & 2 & 112 \\
\hline & Italy & 35 & 40 & 122 & 28 & 867 & 9 & 1101 \\
\hline & UK & 0 & 3 & 19 & 3 & 7 & 8 & 40 \\
\hline & Total & 37 & 45 & 152 & 124 & 876 & 19 & 1253 \\
\hline
\end{tabular}

\subsection{The Study During the Second Lockdown}

\section{Reference Sample}

The survey has been repeated during October and December 2020, the second lockdown, in Italy, Greece and UK. Among the participants surveyed, 38.4\% were male; the age ranges from 18 to 70 with an average of 40.18 (median equal to 39 ). 


\section{Data Analysis}

Over $62 \%$ of the sample declared, that before the pandemic they moved from their habitual residence for pleasure trips, with a frequency of "1-2 times a year". Only $10.27 \%$ of respondents said they never travelled frequently for pleasure trips.

In this second wave, a non-surprising $100 \%$ of the respondents declared that they had not been forced to cancel a planned pleasure trip during the period of the coronavirus constraint. The basis was not only the fear of booking a trip that was not feasible, but especially the travel restrictions imposed by governments.

In reference to the question "How soon, after the coronavirus constraint is over, will you take a holiday?", $37.07 \%$ declared "after 2-3 month", $27 \%$ "after 1 year"; $7.8 \%$ said "during the first month" and $4.37 \%$ replied "never".

The sea remains the preferred location for the first pleasure trip after the lockdown $(36.58 \%)$. This tendency, is also confirmed during the winter season and Christmas time, highlighting that the seaside is the ideal vacation destination for the majority of people. The percentage of people who would like to visit friends or relatives is high (about 20\%). More than 14\% indicates that the mountains are a preferred destination for the first trip.

In this second wave, the willingness to choose locations having a tourist quality/eco-label brand is growing for future trips. On a Likert scale of 1 to 5 ( $1=$ not at all, $5=$ very much), about $70 \%$ of the answers are between 3 and 5 .

The will to travel must face the reduction of spending power. Respondents $(40.36 \%)$ who wanted to take a pleasure trip after the reopening said that its duration would be just a weekend, while $35.98 \%$ said they wanted to take a week long holiday.

Italy is the preferred location by Italians. The same is valid in Greece for people living there.

\subsection{Comparison of Data for the Two Periods}

We want to verify if the concerns about the freedom to travel are related to how much time, after the restrictions, they will go on vacation. We expect that people who declare that they want to go on vacation shortly after the restrictions tend be more worried about the limitations on trips. We use the Chi-Square Test of Independence which determines whether there is an association between categorical variables (i.e., whether the variables are independent or related). The null hypothesis is that there is no relationship between the categorical variables. If you know the value of one variable, it does not help you predict the value of another variable. The alternative hypothesis states that is a relationship between the categorical variables. Knowing the value of one variable does help you predict the value of another variable. Using a chi-square test we can reject the hypothesis of independence ( $\mathrm{p}$-value $=0.002)$, so there is a relationship between the two variables.

However, if we use data form the second wave we cannot refuse the hypothesis of independence $(\mathrm{p}$-value $=0.381)$.

We also want to test if people who declare that they want to go on vacation quickly after the end of the restrictions, tend to declare that they will go for a longer period. Using a chi-square test of independence, we can refuse the null hypothesis of independence between these two variables: Duration and How soon after the period of constraint is over, due to the coronavirus, will you decide to take a holiday? (p- 
value $=0.005361)$. Indeed, among those who declared that they would immediately go on vacation, $26.42 \%$ would go for a week, while among those who declared they would go after one year, only $12.94 \%$ declared they would go for the same amount of days.

Table 3: Two-Way Table: In the Period of Covid Restrictions, What Worries You and to What Extent? - Restrictions on the Freedom to Travel

\begin{tabular}{|l|c|c|c|}
\hline & $\begin{array}{l}\text { In the period of COVID restrictions, what worries you } \\
\text { and to what extent? - Restrictions on the freedom to } \\
\text { travel }\end{array}$ \\
\hline $\begin{array}{l}\text { How soon after the period of constraint } \\
\text { is over, due to the coronavirus, will you } \\
\text { take a holiday? }\end{array}$ & Not at all & Moderately & A lot \\
\hline Never & 43.33 & 26.67 & 30.00 \\
\hline After 1 year & 36.33 & 25.26 & 38.41 \\
\hline After 2-3 months & 27.21 & 26.78 & 46.00 \\
\hline After 4-5 months & 27.69 & 29.64 & 42.67 \\
\hline During the first month & 21.71 & 28.95 & 49.34 \\
\hline Immediately & 19.81 & 20.75 & 59.43 \\
\hline$X$-squared $=27.402, d f=10, p$-value $=0.002249$ & & \\
\hline
\end{tabular}

Table 4: Two-Way Table: Duration and how Soon after the Period of Constraint Is Over, Due to the Coronavirus, Will You Take a Holiday? (first wave)

\begin{tabular}{|l|c|c|c|c|c|}
\hline \multirow{2}{*}{$\begin{array}{l}\text { How soon after the period of } \\
\begin{array}{l}\text { constraint is over, due to the } \\
\text { coronavirus, will you take a holiday? }\end{array}\end{array}$} & \multicolumn{5}{|c|}{ How long will the first trip last? } \\
\cline { 2 - 6 } & 1 month & 1 week & $7-15$ days & $\begin{array}{c}\text { More than } \\
\text { month }\end{array}$ & Weekend \\
\hline After 1 month & 2.45 & 36.71 & 12.94 & 2.1 & 45.8 \\
\hline After 2-3 months & 2.6 & 36.88 & 18 & 1.3 & 41.21 \\
\hline After 4-5 months & 3.58 & 40.07 & 14.66 & 0.65 & 41.04 \\
\hline During the first month & 4.03 & 33.56 & 16.78 & 1.34 & 44.3 \\
\hline Immediately & 2.83 & 32.08 & 26.42 & 6.6 & 32.08 \\
\hline$X$-squared $=34.043, d f=16, p$-value $=0.005361$ \\
\hline
\end{tabular}

Source: our elaboration on first survey data

These results tend to be also confirmed in the second round of the interview. Also in this case we reject the null hypothesis of independence between the two variables. 
Table 5: Two-Way Table: Duration and How soon after the Period of Constraint is over, due to the Coronavirus, will you take a Holiday? (second wave)

\begin{tabular}{|l|c|c|c|c|c|}
\hline \multirow{2}{*}{$\begin{array}{l}\text { How soon after the period of } \\
\text { constraint is over, due to the } \\
\text { coronavirus, will you take a holiday? }\end{array}$} & 1 month & 1 week & $7-15$ days & $\begin{array}{c}\text { More than } \\
1 \text { month }\end{array}$ & Weekend \\
\cline { 2 - 6 } & 1.43 & 33.57 & 12.86 & 1.43 & 50.71 \\
\hline After 1 month & 3.08 & 32.82 & 24.62 & 3.59 & 35.9 \\
\hline After 2-3 months & 3.81 & 44.76 & 10.48 & 1.9 & 39.05 \\
\hline After 4-5 months & 10.26 & 35.9 & 12.82 & 0 & 41.03 \\
\hline During the first month & 0 & 35 & 40 & 0 & 25 \\
\hline Immediately & 0.002452 \\
\hline -squared $=36.516, d f=16, p$-value $=0.5$ & & \\
\hline
\end{tabular}

Source: our elaboration on second survey data

We decide to test if there is a gender difference in the type of vacation. We see that for both genders, the seaside is the preferred destination, however while about $25 \%$ of female respondents would visit a friend or relative as a first vacation, just $15 \%$ of male respondents declared the same. There is a significant relationship between these two variables ( $p$ value almost 0 ). The same results hold for the second wave of the questionnaire.

\section{Conclusions}

Global tourism has resisted the effects of the terrible events of recent years quite well (Bonham et al., 2006). Travelers seem to have always adapted to threats by changing their destination choices and sometimes changing their usual habits. Following break-up events, in many countries the recovery of the tourism sector has been very slow and difficult. In the case of the SARS epidemic, the connection with travelling can be considered even closer. In the first phase, travelers were the carriers of the disease; subsequently, travel and tourism fell victim to the epidemic (WilderSmith, 2006). This epidemic created a strong sense of anxiety generated by the lack of knowledge of the virus, the ease of transmission and the speed of its diffusion, especially in some environments such as on board aircrafts (Wilder-Smith, 2006). At that time, the World Health Organization published a series of travel guidelines (for example, the advice to postpone non-essential travel). The aim was to limit a viral spread internationally.

The various terrorist attacks of recent years, together with the Gulf wars and the war in Afghanistan, have increasingly served to give enormous and crucial importance to traveler safety issues (Brondoni, 2016). Whether it was wars, terrorist attacks or viral epidemics, while affecting the propensity to travel, no event has however led to a long-term decline in the global development of tourism.

This would suggest that tourism as a system has always been resistant to external shocks. Most likely because most of the breakdown events that have occurred over the years have always allowed changes to destinations without risk. This, however, did not occur with the Covid-19 pandemic: governments around the world adopted restrictive measures regarding internal and external travel for a fairly long period, 
increasing a sense of anxiety and fear in tourists. Motivation and emotion are fundamental for tourism as is the choice to take a trip (Reitano et al., 2006). The global impact of the recent COVID-19 virus has had a disruptive impact on the planet in unprecedented ways. How we negotiate the new realities around this virus, other global health and security issues, chaos in financial markets, and environmental crises in the near future, will require a range of adaptive strategies that are inherently resilient and sustainable (Fennel, 2020).

Numerous tests lead us to think that the impact and recovery from this event will have no precedent (Gossling et al., 2020). The Covid-19 crisis should be seen as an opportunity to critically reconsider the growth trajectory of tourism and question the logic of more arrivals that imply greater benefits. This may begin with a review of the positive results of the Covid-19 pandemic. For example, following the significant drop in demand, airlines have started phasing out old and inefficient aircraft ${ }^{2}$. Videoconferencing, a missed opportunity to reduce transportation demand (Banister $\&$ Stead, 2004) for years, has been widely adopted by home office workers, including students forced to distance learning and business travelers who avoid non-essential air travel. As stated by Cohen et al. (2018), many business travelers will appreciate the opportunity to fly less. In general, we are moving towards a more sustainable system.

After the first lockdown, there was no desire to move to less crowded places, closer to the concepts of social distancing, such as farm holidays, villages and mountains. This trend changed during the second lockdown period, where there was a significant increase in preferences for mountain locations.

This trend could partly be generated by the onset of the winter period, partly by a renewed feeling of anxiety and fear triggered by a second pandemic wave and the appearance of new variants of the virus.

From a consumer-tourist perspective, both waves of the survey show that people are more comfortable to take a pleasure trip after 2-3 months after the reopening. This highlights that it is necessary to overcome a status of fear and anxiety. The seaside is the favourite destination for $42.36 \%$ in the first wave and for $36.58 \%$ in the second one. This was expected in the first wave, close to the summer, but the confirmation from the second wave (during the winter) highlights that the sea is the preferred holiday destination in general. The second survey in comparison to the first, regarding the time within which to take a leisure trip after reopening, shows an increase in the desire to leave one year after reopening and a decrease in the desire to take a trip during the first month. Again, a consolidated state of anxiety and fear and a greater awareness on the part of tourists to comply with the regulations.

The common will, both for Italians and Greeks, is not to move away from their country of origin (domestic tourism). This tendency is not same for the UK and the will of the residents is to leave the country. Comparing the two surveys, we found that a high percentage of people want to visit friends or relatives. This tendency is valid more for women than for men.

The repercussions of the period of constraint are also evident in relation to the duration of the first post-Covid vacation. About $77 \%$ of respondents are divided between weekend trips or week-long trips. Among those who said they would go on holiday immediately, $26.42 \%$ would go for a week, while among those who said they would go after a year, only $12.94 \%$ said they would go for the same number of days. Finally, after the second lockdown, the willingness to seek out destinations with 
quality/eco-labels is growing. This confirms a consolidated need for guarantees in compliance with standards and rules.

\section{Bibliography}

Banister, D., \& Stead, D. (2004). Impact of Information and Communications Technology on Transport. Transport Reviews, 24(5), 611-632. http://dx.doi.org/10.1080/0144164042000206060

Bonham, C., Edmonds, C., \& Mak, J. (2006). The Impact of 9/11 and Other Terrible Global Events on Tourism in the United States and Hawaii. Journal of Travel Research, 45(1), 99-110. http://dx.doi.org/10.1177/0047287506288812

Brondoni, S.M. (2016). Global Tourism and Terrorism. Safety and Security Management. Symphonya Emerging Issues in Management (symphonya.unimib.it), (2), 7-16.

http://dx.doi.org/10.4468/2016.2.02brondoni

Brondoni, S. M. (2016). Global Tourism Management. Mass, Experience and Sensations Tourism, Symphonya. Emerging Issues in Management (symphonya.unimib.it), (1), 7-24.

http://dx.doi.org/10.4468/2016.1.02brondoni

Brown, A., Ahmad, S., Beck, C., \& Nguyen-Van-Tam, J. (2016). The Roles of Transportation and Transportation Hubs in the Propagation of Influenza and Coronaviruses: A Systematic Review. Journal of Travel Medicine, 23(1), tav002.

http://dx.doi.org/10.1093/jtm/tav002

Burkle, F.M. Jr. (2006). Globalization and Disasters: Issues of Public Health, State Capacity and Political Action. Journal of International Affairs, 59(2), 231-265.

Cordesmeyer, M., \& Papathanassis, A. (2011). Safety Perceptions in the Cruise Sector: A Grounded Theory Approach. In Gibson, P., Papathanassis, A., \& Milde, P. (Eds.) Cruise Sector Challenges, Gabler Verlag.

Cohen, S.A., Hanna, P., \& Gössling, S. (2018). The Dark Side of Business Travel: A Media Comments Analysis. Transportation Research Part D: Transport and Environment, 61, 406-419.

http://dx.doi.org/10.1016/j.trd.2017.01.004

Dong, E., Du, H., \& Gardner, L. (2020). An Interactive Web-Based Dashboard to Track COVID-19 in Real Time. The Lancet. Infectious Diseases, 20(5), 533-534.

http://dx.doi.org/10.1016/S1473-3099(20)30120-1

Fennel, D. A. (2020). Technology and the Sustainable Tourist in the New Age of Disruption. Journal of Sustainable Tourism, 29(5), 1-7.

http://dx.doi.org/10.1080/09669582.2020.1769639

Goodman, L. A. (1961). Snowball Sampling. The Annals of Mathematical Statistics, 32(1), 148-170.

Gössling, S., Scott, D., \& Hall, C. M. (2020). Pandemics, Tourism and Global Change: A Rapid Assessment of COVID-19. Journal of Sustainable Tourism, 29(1), 1-20.

http://dx.doi.org/10.1080/09669582.2020.1758708

Higgins-Desbiolles, F. (2020). Socialising Tourism for Social and Ecological Justice after COVID19. Tourism Geographies, 22(2), 610-623.

http://dx.doi.org/10.1080/14616688.2020.1757748

Hoque, A., Shika, F. A., Hasanat, M. W., \& Arif, I. (2020). The Effect of Coronavirus (COVID-19) in the Tourism Industry in China. Asian Journal of Multidisciplinary Studies, 3(1), 52-58.

Lambin, J. J. (2002). Strategic Marketing Revisited after September 11. Symphonya. Emerging Issues in Management (symphonya.unimib.it), (1), 7-27.

http://dx.doi.org/10.4468/2002.1.02lambin 
Laws, E., \& Prideaux, B. (2005). Crisis Management: A Suggested Typology. Journal of Travel \& Tourism Marketing, 19(2-3), 1-8.

http://dx.doi.org/10.1300/J073v19n02_01

Lee, A. (2020). Wuhan Novel Coronavirus (COVID-19): why Global Control Is Challenging? Public Health, (179), A1-A2.

http://dx.doi.org/10.1016/j.puhe.2020.02.001

Mallapaty, S. (2020), What the Cruise-Ship Outbreaks Reveal about COVID-19. Nature, 580(7801), 18.

http://dx.doi.org/10.1038/d41586-020-00885-w

Miller, G., Twining-Ward, L. (2005). Monitoring for a Sustainable Tourism Transition. The Challenge of Developing and Using Indicators. CABI Publishing, Wallingford.

http://dx.doi.org/10.1079/9780851990514.0000

Nepal, S. K. (2020). Travel and Tourism after COVID-19-Business as Usual or Opportunity to Reset? Tourism Geographies, 1(1), 1-5.

http://dx.doi.org/10.1080/14616688.2020.1760926

Peiris, J. S., Yuen, K. Y., Osterhaus, A. D., \& Stohr, K. (2003). The Severe Acute Respiratory Syndrome. N Engl J Med, 349(25), 2431-41.

http://dx.doi.org/10.1056/NEJMra032498

Postman, A., Yeoman, I. S. (2021). A Systems Perspective as a Tool to Understand Disruption in Travel and Tourism. Journal of Tourism Futures, 7(1), 67-77.

http://dx.doi.org/10.1108/JTF-04-2020-0052

Ready, K. J., \& Dobie, K. (2003). Real and Perceived Terrorist Threats: Effects of September 11, 2001 Events on the U.S. Motorcoach-Based Tourism Industry. Journal of Travel and Tourism Marketing, 15(1), 59-76.

http://dx.doi.org/10.1300/J073v15n01_04

Reitano, A., Servidio, R., Feraco, A., \& Pantano, E. (2006). Emotion and Reason in the Buying Process of Tourist Product, in Vranesevic Tihomir, Pavicic Jurica (eds.), Proceedings "The 3rd International Customer Behavior and Retailing Research Conference". Graduate School of Economics \& Business, University of Zagreb, 21-22 April, 105-116.

Reitano, A., Fazio, M., \& Taylor, D. W. (2016). Traceability of Food Products in Global Gastronomic Tourism. Symphonya Emerging Issues in Management (symphonya.unimib.it), (2), 46-59.

http://dx.doi.org/10.4468/2016.2.06reitano.fazio.taylor

Salvioni, D. M. (2016). Hotel Chains and the Sharing Economy in Global Tourism, Symphonya.

Emerging Issues in Management (symphonya.unimib.it), (1), 31-44.

http://dx.doi.org/10.4468/2016.1.04salvioni

Škare, M., Soriano, D. R., \& Porada-Rochoń, M. (2021). Impact of COVID-19 on the Travel and Tourism Industry. Technological Forecasting and Social Change, 163, 120469.

http://dx.doi.org/10.1016/j.techfore.2020.120469

Wilder-Smith, A. (2006). The Severe Acute Respiratory Syndrome: Impact on Travel and Tourism. Travel Medicine and Infectious Disease, 4(2), 53-60.

http://dx.doi.org/10.1016/j.tmaid.2005.04.004

Yang, Y., Zhang, H., \& Chen, X. (2020). Coronavirus Pandemic and Tourism: Dynamic Stochastic General Equilibrium Modeling of Infectious Disease Outbreak. Annals of Tourism Research, 1-22. http://dx.doi.org/10.1016/j.annals.2020. 102913

Zhong, N. S., Zheng, B. J., Li, Y. M., et al. (2003). Epidemiology and Cause of Severe Acute Respiratory Syndrome (SARS) in Guangdong, People's Republic of China. Lancet, 362,1353-1358. http://dx.doi.org/10.1016/S0140-6736(03)14630-2

Zillman, C. (2015). Terrorism's Effect on Tourism Doesn’t Last Very Long. Fortune, November 30. 
SYMPHONYA Emerging Issues in Management, 2, 2021

symphonya.unicusano.it

Notes

${ }^{1}$ WHO. Novel coronavirus (2019-nCoV) situation report - 11 (website). WHO; 2020. 31 January 2020. Available at:

https://www.who.int/docs/default-source/coronaviruse/situation-reports/20200131-sitrep-11ncov.pdf?\%20sfvrsn\%C2\%BCde7c0f7_4 (Accessed February 3, 2020).

${ }^{2}$ Simple Flying. (2020). United could follow American with early $757 \& 767$ retirement. Retrieved April 7, 2020, from https://simpleflying.com/united-757-767-early-retirement/ 